throughout are elear and woll labelled. 'The choice of instruments for detailed description reflects tho author's own special interests. Thus, polarization interferometers are covered in dotail. The chapter on interference spectroscopy, however, deals mainly with Fourior transform instrumonts and dismisses the now widely used FabryPerot photoclectric spectromoter in half a page. (Displacement of the plates to produce optical path variation, far from being "much too coarse", is now nearly as common as pressuro scanning.)

Transient interference beats and fringos from laser sources, and optical holography are concisely and clcarly discussed, but experimental details in the chapters on thin films and multiple bcam interference are somewhat sketehy. Nevertheless this book looks like becoming a standard undergraduate text.

\section{J. BRADLFY}

\section{SOUNDS VALUABLE}

Ultrasonic Machining of Intractable Materials

By A. I. Markov. Edited by E. A. Neppiras. Translated by Seripta Technica, Ltd. Pp. 350. (London: Iliffe Books, Ltd., 1966.) 63s. net.

THE book deals with the ultrasonic machining of hard brittle materials and the use of vibrations to assist in conventional grinding and cutting operations. It would appear that, in both these ficlds, the majority of research and development work has been earried out in Russia and it is of great value to have an English edition of the original Russian book.

The main section of the book dealing with ultrasonic machining first introduces ultrasonic vibrations in a simple and readily understandable way and thon shows how these can be applied to machining. Chapters dealing in detail with the design of ultrasonic generators, acoustic heads and ultrasonic machine tools are ineluded together with a very comprehensive and eritical survey of rescarch in the subject. The technology and industrial uses of ultrasonic machining aro dealt with in a fundamental manner. The final section of the book is dovoted to discussions of the benefits to be obtained by sonic and ultrasonic vibrations in drilling, grinding, thread eutting and turning.

In my view this book is an excellent example of how a technological subject should be treated; it is very readable and uses a fundamental approach throughout. The book will be of great value to those involved in teaching production processes and those in industry interested in the applications of modern developments in production techniques.

G. Boothroyd

\section{RARE EARTHS}

\section{Progress in the Science and Technology of the Rare} Earths

Fdited by LoRoy Eyring. Vol. 2: Pp. 366. (Oxford, London and New York: Pergamon Press, Ltd.. 1966.) $105 s$. net.

THw incroasing use of the rure earths in industry is brought out in the well organized chapter (and extremely well urranged bibliography) on their uses and applications contributed by H. H. and R. M. Mandle. This chapter takes up nearly one third of the book, which covers muinly the work published from 1961 to early 1965 . The other entributions are also written by acknowledged experts in tho fiold. They are J. H. van Vleok, who writes on the molecular ficld model of exchange coupling in rare sarth materials; A. H. Daane, on recent improvements in mothods of preparing rare earth metals; E. F. Westrum, jun., on thermodynamic and magnetic proper- ties of the rare earth chalcogenides and pnictides; R. E. Thoma, on the rare earth halides; W. Low, on some physical propertios of mixed cation oxides; D. I. Ryabchikov and E. K. Korchemnaya, on rare carth metal comploxes, which provides a review of recent Russian work; and (y. Brauer, on structural and solid state chemistry of pure rare earth oxides.

The coverage in all eight chapters is comprehensive for the period coneerned and the bibliographies are very good. Although the author index is satisfactory, the subject matter could have been indexed in much grcater detail, so making it easier to pick out specific pieces of information. There is an appreciable number of typographical errors (for example, refs. $b$ and $d$ of Table 3, page 103), and although these are all trivial, they tend to irritate the reader, and, furthermore, data and spectra are plural.

Apart from these few imporfections, the book is well produced and should be very useful to those interosted in the field.

K. W. Bagmati.

\section{FLOW OF FLUID}

\section{Fluid Mechanics of Internal. Flow}

Edited by Gino Sovran. (Proceedings of the Symposium held at General Motors Rescarch Laboratories, Warren. Michigan, 1965.) Pp. xi+336. (Amsterdam, London and New York: Elsevier Publishing Company, 1967.) $135 s$.

INTERNAL flows, although of great technical importance, have in recont years barely received the same fundamental treatment afforded their more overtly aeronautical counterpart, the external flows about bodies. The problems thoy pose, however, are frequently as interesting and often more difficult, as the procoodings of this symposium, ably edited by Dr. Sovran, display.

Many facets of the subject are dealt with: turbulent boundary layer devclopment, secondary flows and the behaviour of diffusers, charactoristically from a fundamontal standpoint by an imposing list of authors including such names as Ackeret, Rotta, Kline and Hawthorne. While certain of the papers, notably those dealing with boundary layer transition and turbulence, could equally well have appeared in a symposium on oxternal flows, they mostly boar the stamp of freshness (often lacking in the modern ploy of binding symposium papers botween hard covers!) and, because of their incisive scicntific approach to the subject, provide stimulating ideas for further investigation.

One very welcome (and unusual) feature of the book is the relevance of the open discussions that appear at the end of each paper. These discussions make informative and occasionally delightful reading; like the diatribe by Dr. Liepmann against the random nature of turbulonee research-"it cannot be done by one Ph.D. student followed by another Ph.D. student followed by another Ph.D. studont, because they'll never agren".

This is a book that can be recommended to workers concerned not only with internal flows but with fluid mechanies generally.

P. R. OweN

\section{NEW IONS FOR OLD}

\section{Ion Exchange}

A Serios of Advances. Edited by Jacob A. Marinaky. Vol. 1. Pp. $x i+424$. (London: Fdward Amold (Publishers), Ltd.; Now York: Marcel Dekker, Inc., 1966.) 135s, net.

WF are told in the preface to this book that "Speculation was sought from each of the distinguished authors of this volume to provide each chapter with a broader base than a technical paper and also to enable each chapter to be 